\title{
Putting a Face on the Pathogen and Its Nemesis
}

\section{Images of Tenkeisei and Gozutennō, Epidemic-Related Demons and Gods in Medieval Japan}

\author{
Katja Triplett | ORCID: 0000-0002-8434-1608 \\ Centre for Advanced Studies in the Humanities and Social Sciences \\ "Multiple Secularities-Beyond the West, Beyond Modernities," \\ Leipzig University, Leipzig, Germany \\ katja.triplett@uni-leipzig.de
}

\begin{abstract}
In medieval Japan, so-called "four boundary demarcation rituals" were believed to turn invisible epidemic disease-bringing "demons" into visible beings. Making the demons visible, at least to the ritual experts involved, was a way of controlling them. The demons had a dual nature in that they harmed humans but could also become powerful protectors against disease and other calamities. This essay introduces the elaborate ritual culture of yin-yang divination, esoteric Buddhism, and kami worship in Japan, all of which involve "demonic" and protective deities. It explores images of two epidemic demons that serve humans as guardians and protectors against epidemic disease: Tenkeisei 天刑星, the Star of Heavenly Punishment, and Gozutennō 牛頭天王, the Bull-Headed Divine King. Tenkeisei ultimately merged with Gozutennō, who is also conflated with the deity Susanoo 素戔鳴.
\end{abstract}

\section{Keywords}

Japan - demons - epidemics - smallpox - Tenkeisei 天刑星 - Gozutennō 牛頭天王

\section{Introduction: Putting a Face on the Pathogen}

Since April 2020 the image of a sphere with menacing spikes has accompanied virtually every report on the novel coronavirus. It appears monumentally enlarged in the background of newscasts about the spread of SARS-CoV-2 and 
the policies to stop it. The overdimensional depiction of this inestimably tiny pathogen frightens viewers, the impact amplified by the use of the threatening colors red, black, and purple. Such images are created to look dangerous and intimidating, instilling disquiet and a sense of alarm. They are especially frightening to young children. When the first news reports about the coronavirus outbreak were broadcast and the picture of the hugely enlarged pathogen modeled on its shape as seen under the electron microscope started to appear, I overheard a conversation on the bus between a mother and her young son. The boy seemed very concerned about the news of a life-threatening disease and asked his mother in German whether "the huge balls with pins are going to come and attack us."

While the iconic spiky ball somehow looks abstract, some have started putting a face on the shape and thus have given it a personality and a different sort of agency. Now we can literally face the pathogen, we can communicate with it and fight it, in a personal or collective battle for survival. This perspective is mirrored in some of the martial metaphors used by politicians around the world when speaking about coronavirus. In recent months, crafters looking to kill some time-and save lives-have designed crochet dolls of the coronavirus-some with happy faces, some that are waspish in appearance. I was struck by the large number of photos of crocheted virus dolls posted online, and started collecting other examples of the spiky ball image from newspapers and magazines, fascinated by the creative ways it had been used. ${ }^{1}$

The urge to put a face on the pathogen seems to enable humans to better "face" the "enemy." In medieval Japan, from about the eighth century onward, rituals of purification of the four boundary demarcations were believed to turn invisible epidemic disease-bringing agents into visible beings. These "Rituals of the Four Boundary Demarcations" (shikai no matsuri 四堺祭) 2 took place when the clerical leaders felt that epidemics threatened to take hold of the inhabitants of the capital. There were also other regular festivals (matsuri) that aimed to protect the dwellers of a particular settlement from malign influences. The earliest available records of official rituals for the protection of the boundary roads around the capital against "unseen" evil forces are found in the eighth-century regulations of the then newly established Department of Divinities (Jingikan 神祇官). These regulations ${ }^{3}$ determined, for instance, the

1 For examples, please see the editors' introduction to this issue.

2 Similar festivals include the "Festival of the Four Boundaries" (shikyōsai 四境祭), the "Festival of the Four Corners" (shikakusai 四角祭), and the "Border Festival" (sakai no matsuri 境祭).

3 The regulations are found in the Jingiryō 神祇令, "Divinities Prescriptions" or "Kami Law." See Hardacre 2016, 31-33. 
occasion and the course of the "Feasting of the Roads Festival" (michiae no matsuri, also chiae no matsuri 道饗祭) that was supposed to protect Nara, the imperial capital at the time, from calamities. But in the year 735, an epidemic broke out in Kyushu, ${ }^{4}$ and Feasting of the Roads Festivals were also celebrated in the affected areas far away from Nara. In the eighth century, Buddhism had already taken root in Nara and elsewhere in the emerging centralized state on the Japanese archipelago. Buddhist rituals of the Nara period (710-794) already included esoteric Buddhist rituals. Buddhism coexisted with a system of worship of the kami, the local gods, and other deities that was modeled on Chinese-style rituals and rites: The Feasting of the Roads Festivals, performed by diviners (urabe 卜部), clearly contained elements of Chinese-style yin-yang divination that in Japan is referred to as the Way of Yin and Yang (onmyōdo 陰 陽道5). ${ }^{6}$ This multifaceted religious system in Japan eventually morphed into a more complex system in which kami, Daoist gods, Indian deities, Buddhist divinities, and various kinds of spirits and other superhuman beings began to form a "fluid pantheon," to use Bernard Faure's expression, ${ }^{7}$ worshiped and celebrated in a number of ways.

The Feasting of the Roads Festival was merged into rituals that had a similar purpose; namely, to ward off epidemics and catastrophes. The capital was for various reasons moved from the Yamato basin to another location further north. ${ }^{8}$ Modeled on the capital of the Tang dynasty Chang'an that the Japanese ruling elite greatly admired, the new capital Heian-kyō was inaugurated in 794 to match the geomantic rules of an ideal topographical site for the central seat of power. Great care was taken to position the city according to Chinese geomantic knowledge so that evil influences could not enter and harm the

4 The smallpox epidemic lasted from 735 to 737 . It entered Japan from Korea and is well documented in contemporary sources; see Farris 1985, 142. See also Como 2007. Farris introduces various archaeological sources that give additional evidence of the impact the frequent epidemic outbreaks had on ancient society in Japan. He also outlines ritual responses and other aspects of Nara and Heian religion (Farris 2009, 42-52).

5 The characters are normally read on'yōdō today. For the different readings, see Miyata 2012, 119n1. For a standard introduction to the history of the Way of Yin and Yang in Japan (in Japanese), see Murayama 1981. For an outline in English, see Hayashi and Hayek 2013.

6 For an exploration of mantic practices in East Asian Buddhist texts, see Guggenmos 2017.

7 Faure 2016a.

8 For standards works (in English) on the historical context referred to in this paragraph, see the contributions to the second volume of The Cambridge History of Japan, on Heian Japan (Shively and McCullough 1999). The Heian period is named after the new capital of Heian-kyō (Kyoto). For more on the history of community festivals, see, for example, Naumann 2000; on festivals and warding off evil, see ibid., 54-56. A recent overview on the history of kami worship is found in Hardacre 2016. 
imperial family and thus the state. Heian-kyō, known under the name Kyōto or Miyako, remained the capital of the Japanese empire for over ten centuries although the seat of the military governments kept shifting to other places during that time. The "Miyagi Four Corner Epidemic Gods Festival" (Miyagiyosumi ekijin-sai 宮城四隅疫神祭) that integrated the ancient Feasting of the Roads Festival seems to have been celebrated regularly in the new capital. As severe epidemics kept decimating the population not only of Kyoto but also of other places in Japan up until about 1050, festivals and Buddhist rituals dedicated to border deities ${ }^{9}$ and divine protectors were a regular occurrence. The bestknown example is perhaps the Gion Festival (Gion goryōe 祇園御霊会, Gion matsuri 祇園祭り) in Kyoto, which was first celebrated in 869 after an outbreak of an epidemic and became an annual festival in 970. The period after $105^{\circ}$ until about 1260 can be seen as a transitional phase in which smallpox and measles slowly became endemic, at least in some parts of the country. ${ }^{10}$ While historical sources describe the symptoms of the epidemic diseases in detail, it is difficult to identify the diseases with certainty. It appears that Japan was hit by outbreaks of smallpox, measles, rubella, mumps, dysentery, and influenza. People were also afflicted with Hansen's disease (leprosy) and tuberculosis. ${ }^{11}$

These diseases were thought to be caused by a group of beings that are often subsumed under the term "demon" in modern literature as a translation of the Chinese character 鬼 (Ch. gui, Jpn. ki, oni; also: mono). ${ }^{12}$ One could call these beings supernatural, but in the medieval period they were thought to be real and natural entities, and the invisible antagonistic souls or spirits of the ancestral dead. ${ }^{13}$ They could enter the human body and cause a particular kind of "worms" that reside inside the body to make the body sick. ${ }^{14}$ The same demons were also described as protectors and thus had a dual nature similar to the kami who are thought to have a wild nature (ara-mitama 荒御魂) and a mild

9 Border deities include Funado no kami or Kunado no kami 岐の神 and a group of such deities called sae no kami さえの神 or dōsojin 道祖神. The cult of the border deity also merged with the Buddhist cult of the bodhisattva Jizō 地蔵 who is believed to assist those traveling on the road from this world to the next.

10 Cf. McNeill (1976) 1998, 152-54.

11 For a timeline of reports on outbreaks of contagious diseases in premodern Japan, see Fujikawa 1912, 11-66.

12 For the different uses of the character 鬼 and images of the oni in ancient and medieval Japan, see Baba 2000, 35-40.

13 These malevolent spirits of the dead (onryo 怨霊, goryo 御霊) were feared because they curse the living and take revenge by causing calamities and epidemics; regular worship could turn them, however, into benign kami. See McMullin 1988.

14 According to Chinese-style medicine, the so-called Three Deathbringers (sanshi 三尸) and the Three Worms (sanchü 三虫) living inside the human body can cause disease. 
nature (nigi-mitama 和御魂). The demons, oni, represented the "other" entering this world from the land of the dead or from "abroad," crossing the borders and boundaries of the land, the human settlements, and the inhabitants' bodies. They entered human bodies and possessed them, making them mad or sick. Indeed, Heian-period court literature speaks of "demons in the mind or heart" (kokoro no oni 心の鬼) when referring to dark and painful human feelings of envy, scorn, and anger.

\section{Controlling Demonic Beings: Exorcism Rituals}

The Way of Yin and Yang practitioners had various kinds of exorcism rituals to treat the demon-afflicted mind and the possessed body. In the heyday of onmyōdō practice in the tenth century, the Bureau of Yin and Yang (Onmyō-ryō 陰陽寮) employed men to calculate the almanac, measure time with water clocks, observe the night sky, and assess natural phenomena to divine and influence future events. ${ }^{15}$ It was believed that there was a resonance between the "stars" ( hoshi 星) — celestial bodies in general — and the world of humans. ${ }^{16}$ If humans misbehaved, the star gods that reside on the celestial bodies would send heavenly_or rather "hellish" - punishments such as storms, earthquakes, tsunami, pests, and epidemic diseases. Ritual experts strove to avert these heavenly punishments by influencing the star gods. The yin-yang masters used various instruments and methods. Apart from sacred spells ( $j u$ 咒) and scriptural recitation, they created seals for healing and talismans ( $f u$ 符) for summoning the gods of celestial constellations and other cosmic deities so that these could assist humans in various ways. The cosmic deities include menacing or "baleful" stars (yōsei 妖星) which were comets or large shooting stars. ${ }^{17}$ The yin-yang masters' ritualistic efforts particularly targeted epidemic demons that infected humans in order to extract offerings from them. Some of the charismatic divination masters also served courtiers in battling demons and each other.

One way of controlling the demons was to make them visible, at least to yinyang masters, with spells, rituals, and other methods. Humans in general were assumed to see the corporeal presence of demons either by chance, through

15 For more on the "Way of Yin and Yang" in Japan (in English), see Itō 2003, 97-101; Hayashi and Hayek 2013 .

16 On the worship of stars in Japan, see contributions in a special issue of the journal Culture and Cosmos, edited by Lucia Dolce 2006.

17 For the tradition of baleful stars in Chinese religion, see Hou 1979. 
ongoing practice, or because of an inborn talent. One tale of the Anthology of Tales from the Past (Konjaku monogatarishū 今昔物語集), a large collection of moralistic and entertaining tales from the late Heian period, relates how the special giftedness of Kamo no Yasunori 賀茂保憲 (917-977), who was to become a famous master, became apparent when he was only a young child:

Little Yasunori was present when his father, the yin-yang diviner Kamo no Tadayuki 賀茂忠行 [?-96o?] conducted a purification ritual. To the amazement of his father the boy said afterwards while they were riding home in a carriage: "Daddy, during the purification I saw lots of people. They looked like people but they weren't, and they were very scary. They ate up the food offerings, then they got on the little boats, carriages, and horses you'd laid out and they all went away. What were they, Daddy?"18

Both Tadayuki and his son Yasunori were important ritualists at court and had numerous private patrons for their art. They were also the teachers of Abe no Seimei 安倍晴明 (921-1005) who became the most revered yin-yang master of his age. Even during his lifetime, Abe no Seimei was a legend who enjoyed the support of Ichijō Tennō 一条天皇 (980-1011; r. 986-1011), the emperor, and powerful politicians, men and women, at court (see Miyata 2012). He was also allegedly knowledgeable about medical matters. Yasunori's son, Kamo no Mitsuyoshi 賀茂光栄 (939-1015), who is said to have shared his grandfather's and father's talents, also became a yin-yang master.

Despite Abe no Seimei's and Mitsuyoshi's brilliance, training, and experience, one of Yasunori's daughters contracted a disease called mogasa もがさ19 (smallpox). Some scholars claim she survived the disease, while others say she succumbed to it and died. The disease affected her eyesight, which she partially lost. The daughter's name has long been forgotten-she is referred to only as Kamo no Yasunori's daughter-but the outstanding poetry she wrote during her illness has survived for a millennium. The poems are particularly stirring because of the way she expresses the physical pain of someone afflicted with smallpox and the mental pain of someone who feels horribly disfigured by the disease - not without a sense of humor when she relates to her own misfortune. ${ }^{20}$

18 Konjaku monogatarishū 24:15, NK в т 24:298 (translation adapted from Tyler 1987, 230-31).

19 痘瘡 hōsō.

20 See Uzumaki 2017, 29-30. 


\section{Depictions of Demonic Attackers and Fierce Guardians}

The cruelty of epidemics such as smallpox, especially in the face of the obvious helplessness of expert ritualists and medical practitioners, ${ }^{21}$ is expressed in the ghastliness of the demons. They are often described and depicted with faces that mix the traits of animals, especially those of predatory mammals or birds, with exaggerated human traits. Conventionally, they are masculine and naked but for a loincloth, which is often made from tiger skin. ${ }^{22}$ Demonic beings and deities of Indian origin found their way into Japanese tradition alongside imaginary beings from China and Central Asia, resulting in a complex and shifting system of antagonistic forces that also have the potential to be beneficial and protective. If revered correctly, the beings can destroy obstacles. One example is the group of the Four World-Protecting Celestial Kings (Gose shitennō 護世四天王), fierce-looking protectors that function as guardians of the four corners of the world and often as gatekeepers of Buddhist temples. They wear heavy military armor and are often depicted as trampling inferior demons, which Buddhists interpret as mental obstacles to dharmic practice. In India, these vanquished demons, jaki 邪鬼 (lit., "evil demons"), used to be part of the Celestial Kings' retinue but when the deities with their respective retinues were integrated into Buddhism, the demons came to represent the conquered "barbarian" enemies in a process of "demonization." The Four Celestial Kings belong to the deva (gods) class of beings in the Buddhist universe. There are other fierce protectors of the Buddhist teachings as well as a great number of fierce spirits, including the Wisdom Kings (Jpn. myōō 明王, Skt. vidyarāja) that aid the practitioner on their path. The Wisdom Kings are regarded as the embodiment of the deep desire to assist suffering beings and are the wrathful emanations of certain buddhas. In contrast to the Four Celestial Kings, they never wear armor but are dressed and adorned as an Indian prince. Like the Celestial Kings, they are depicted with an expression of rage ( funnu-sō 憤怒相) and flamelike bristling hair (dohatsu 怒髪 or enpatsu 炎髪). They usually also hold various kinds of weapons, and some trample on demons. ${ }^{23}$

Another example from the esoteric Buddhist tradition is a demon king from the Vedic tradition that, as a figure called Candana Gandharva (Jpn. Sendan Kendatsuba 梅檀乾開婆), became the focus of a Buddhist ritual for the

21 For an overview in English of the Japanese ancient and medieval medical tradition of treating epidemic diseases, see Fujikawa 1912.

22 On the visual image of the oni, see Reider 2010, 7-9.

23 The female Peacock Wisdom Queen (Mahāmāyūrī vidyārajñī) also belongs to this group of beings. She has, in contrast to the Wisdom Kings, a kind face. 
protection of children and pregnant women from a set of fifteen demons and demonesses. ${ }^{24}$ The fifteen demons and demonesses take the form of various animals as well as a demoness (Skt. rākșasī), a human lady, and a male youth (Skt. kumāra) to harm the children. ${ }^{25}$ The demon that appears as a youth is the god Skanda, and the youthful form is his manifestation as the god Kumāra. Both are also known as guardian deities in Japan.

Demonic deities thought to cause epidemics and havoc entered oral and written literature in Japan from different cultural contexts. In addition to origin stories that relate the former lives of certain deities, we encounter wellknown narratives such as Shuten dōji 酒吞童子, a tale about a demon, Shuten dōji, whose name literally means "drunken lad." ${ }^{26}$

The earliest extant version of the Shuten dōji story is from the fourteenth century. However, the figure of the demon who abducts men, women, and children from the capital to eat them - and who takes the shape of a young boy in the daytime and returns to his real form, a huge red ogre with fifteen eyes and five horns, at night - may have existed in oral tradition long before the fourteenth-century version developed. Historian Takahashi Masaaki, who published a pioneering work on the narrative, asserts that Shuten dōji's original form was an epidemic god. The narrative is set during the reign of Ichijō Tennō and involves Abe no Seimei who divined the cause of the abduction of the people. ${ }^{27}$ The historical background of the story may have been the epidemics and natural disasters that occurred during the reign of Ichijō Tennō, including the smallpox epidemics around the year 993 when Kamo no Yasunori's daughter is assumed to have contracted the disease.

In the story, the two warriors and the Four Celestial Kings (Shitennō) in human form whom the emperor has sent eventually manage to reach the abode of the demon king and free his captives, who include people from China. They also liberate several children from the capital whom the demon king had put in a cage. Among the children is a Buddhist abbot's boy novice (chigo 稚児), the young son of the most powerful courtier of the time, Fujiwara no Michinaga 藤原道長 (966-1027). Tricking the demon king into a drunken stupor, the warriors and their divine helpers eventually cut off the demon king's head, but only when they gouge out his eyes is the ferocious power

\footnotetext{
24 I briefly introduced this figure and the ritual in an earlier contribution to the present journal: Triplett 2019, 328-29.

25 See also Strickmann 2002, 58-88.

26 For recent translations of the tale into English, see Reider 2016, 37-61; Kimbrough 2018.

27 For a discussion of the role of antidemon rituals in shaping the Shuten Dōji emaki 酒吞 童子絵巻, a fifteenth- or sixteenth-century picture scroll from the Suntory Museum, see Phillips 2019.
} 
of the demon broken. Lin assumes that the demon's power is in his eyeballs and that removing them is akin to an "eye-closing ceremony," effectively the opposite of the eye-opening ceremony to consecrate a Buddhist statue. ${ }^{28}$ I would like to propose a slightly different interpretation. It may be that the tale uses the image of Candana Gandharva and his retinue of fifteen demons that are all emanations of himself and his power. If my hypothesis is correct then Shuten dōji's fifteen eyes - a highly unusual, if not unique number in the description of monsters in Japan - point to these fifteen demons. Equally, like Skanda-Candana Gandharva, he manifests as a youth and has red skin in his real form. As such, it may be that the way Shuten dōji is described in the tale is a lost or hidden reference to this demon king and the fifteen demons and demonesses that harm children. ${ }^{29}$

\section{The Pictures of the Extermination of Evil (Nara National Museum)}

In the Buddhist context, Candana Gandharva becomes an "exterminator" of the fifteen evil demons through certain offering rituals. However, he does not seem to have been worshiped for long in Japan. A rare and unconventional picture of him slaying the fifteen demons is found in the twelfth-century picture scroll Pictures of the Extermination of Evil (Hekija-e 辟邪絵). This scroll that, according to art historian Miyajima Shūichi and others, ${ }^{30}$ was created at the behest of Retired Emperor Goshirakawa (1127-92, r. 1155-58) and kept at Rengeō-in Temple ${ }^{31}$ in Kyoto for many centuries, also contains an enigmatic picture of the destruction of Gozutennō 牛頭天王, the Bull-Headed Divine King, and his offspring at the hands of a powerful star deity.

Gozutennō is one of a number of fierce deities that spread pestilence (gyōyakujin 行疫神) but who are also revered as protectors from pestilence. As with most deities in the fluid pantheon of Japan, these deities are the focal points of larger networks that include their retinue, emanations, or offspring. The deities are also conflated with other deities that have an equivalent sphere of competence; whose names can be linked in some way, or who share

28 Lin 2002, 395. The name of such a ceremony is hakken-shiki 撥遣式, “ceremony of expulsion or abandonment."

29 Takahashi (1992) 2005, 96-103, asserts that the epidemic smallpox god was thought to be linked to a creature called $s h \bar{o} j \bar{o}$ 猩々, a red, alcohol-loving water spirit that is reminiscent of Shuten dōji.

$30 \quad$ E.g. Kobayashi 1974.

31 This temple is better known by the name Sanjūsangendō. 


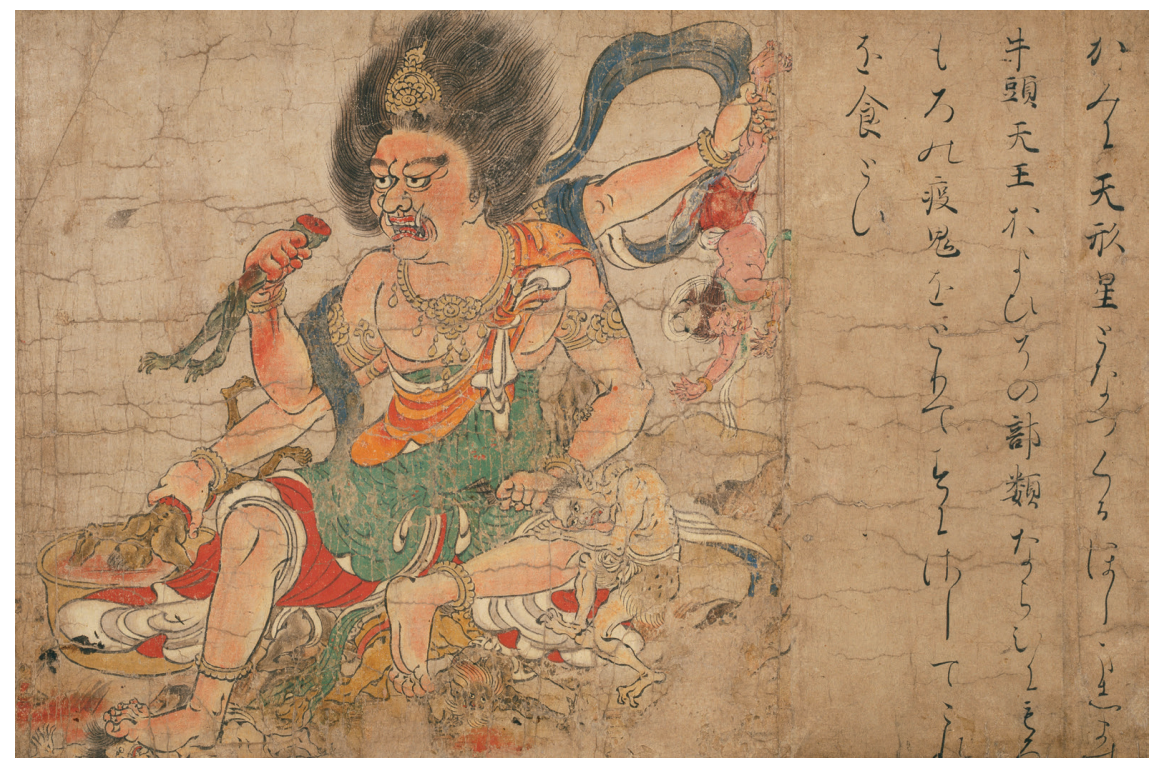

FIGURE 1 Star of Heavenly Punishment (Tenkeisei 天刑星), from the picture scroll Extermination of Evil (Hekija-e 辟邪絵), national treasure, one of five hanging scrolls, color on paper, H. $25.8-26.0 \mathrm{~cm}$, W. $39.2-77.2 \mathrm{~cm}$, Heian period, twelfth century, Nara National Museum Collection, Sign. 1106

particular characteristic features. ${ }^{32}$ In the case of Gozutennō, cultic reverence is also bestowed upon his consort ${ }^{33}$ and the mother of their offspring, the Eight Princelings (Hachiōji 八王子).

Today, the Pictures of the Extermination of Evil is kept at the Nara National Museum. It consists of five sections that were cut from a handscroll in the twentieth century and mounted separately on hanging scrolls. The sections depict scenes of fierce-looking benevolent deities that in one way or another finish off various kinds of demonic entities, among them epidemic demons. The segments also include texts that explain the scenes. The scenes are remarkable in many ways.

32 For an outline of the Gion cult formation, see McMullin 1988; on name linkage, see ibid., p. 277. For a recent study of the medieval Gozutennō belief (in Japanese), see Suzuki 2019. For Shinra myōjin 新羅明神, the "god of Silla (Korea)," a multifaceted deity worshipped in medieval Japan also as the god of pestilence, see Kim 2020.

33 The consort or wife is known under various different names including Harisaijo (or Harisainyo) 婆梨采女. 
One of the sections of the scroll is dedicated to the wrathful Tenkeisei 天刑 星, ${ }^{34}$ literally "the star that [metes out] heavenly punishment."35 In the picture, a majestic fierce-looking deity-Tenkeisei-is sitting on a rock in a relaxed yet somewhat stiff posture, complacently devouring little anthropomorphic creatures (Figure 1). At first glance, one could think he has evil intent. However, Tenkeisei is eating — and thus exterminating- "epidemic demons" (ekiki, ekki 疫鬼), and is therefore rendering a service to those afflicted with an onslaught of these malign demons. Tenkeisei holds a different kind of demon in each of his four hands. His superhuman strength is expressed through fangs that protrude from his mouth, in addition to a fierce but at the same time composedeven empty ${ }^{36}$ _ facial expression and wild, bristling hair. Across his torso, he wears a magnificent red and orange garment with blue rhombus patterns, that is knotted on the left side of his chest. The garment leaves his muscled right shoulder bare. He also wears a green garment with red flowers around his waist and a dark red leg dress. A shining white underlining can be seen on all of the different garments, which accentuates the vibrancy of the colors. Tenkeisei is wearing jewelry around his neck, upper arms, wrists, and ankles, and a crown that is just visible through his shock of hair. He is obviously modeled on the Wisdom Kings (myōō).

A flowing scarf in a startling blue is wound loosely around Tenkeisei's upper pair of arms, adding dynamism and movement to the scene. In his upper right hand, Tenkeisei is holding the lower half of an epidemic demon. He has already eaten the upper half and thus destroyed one of the beings tormenting humans. Tenkeisei's lower right hand is dipping another demon's head into a bowl containing an unidentifiable red liquid, possibly some broth or sauce. The text informs the viewer that Tenkeisei is putting them in vinegar. The bowl or kettle could be a reference to images of the hell realms where the dead are punished by being prepared in large kettles. Now, the torturers themselves are being prepared for consumption in a similar way.

In his upper left hand, Tenkeisei holds a frightened demon by the legs. The demon is most likely Gozutennō because of the bull's horns on his head. The characteristic bull's head on top of the demon's crown is barely visible today because of some damage to the painting at that exact spot. Miyajima (1985, 78) suggests that the bull's horned head may even have been added at a later

\footnotetext{
34 Alternative readings are Tengyōsei and Tengyōshō.

35 The other four sections of the scroll show Candana Gandharva, Bishamonten 毘沙門天, Divine Insect (Shinchū 神虫), and Zhong Kui 鍾㐤 (Jpn. Shōki).

36 See Miyajima 1985,78 .
} 
point in order to accommodate the reference to Gozutennō in the accompanying text. Tenkeisei's fourth hand is pulling the hair of another demon, which is evidently shocked and dismayed. He is squashing another four of these harmful creatures with his feet. Altogether, including the half-eaten one, the picture depicts eight epidemic demons. Miyajima sees a connection to the group of the Eight Princelings, Gozutennō's offspring. ${ }^{37}$ The text, however, only mentions an unspecified group of demons:

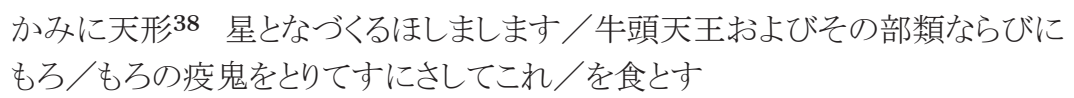

Kami ni Tenkeisei to na zukuru hoshi mashimasu, Gozutennō oyobi sono burui narabi ni moromoro no ekiki wo torite su ni sashite kore wo jiki to su.

The god is a star with the name of Heavenly Punishment Star. It takes various kinds of epidemic demons such as Gozutennō and his group and puts them in vinegar and eats them. ${ }^{39}$

Interestingly, the picture scroll is the earliest representation of the star god Tenkeisei found in Japan. ${ }^{40}$ Rituals involving Tenkeisei are presumed to have been a secret ritual of the Way of Yin and Yang tradition, and thus it is likely that earlier representations of the star deity were rare, and were lost. We are able to understand better how the star deity was celebrated because rituals involving Tenkeisei were included in the esoteric Buddhist system.

\section{Rituals Involving Tenkeisei}

In early medieval Japan, Buddhist monastics conducted and created exorcism rituals with elements from the Yin and Yang tradition. Some of these rituals were clearly intended to exorcise the effect of baleful stars-an area that fell into the domain of the yin-yang masters. ${ }^{41}$

$37 \quad$ Ibid.

38 This character for "shape" is used occasionally instead of the correct kei 刑, "punishment."

39 Text of the Hekija-e (my translation).

40 Ibid.

41 For such a ritual, created by the monk Ningai 仁海 (951-1046), see, for example, Faure 2019, 334. 
Miyajima analyzes three anonymous manuals on conducting esoteric Tenkeisei rituals from the thirteenth and fourteenth centuries ${ }^{42}$ that belong to Kōzanji Temple, located in the mountains northwest of Kyoto: Methods of Tenkeisei Practice (Tenkeisei gyōhō 天刑星行法), Methods of Procedure for the Tenkeisei Practice (Tenkeisei gyōhō shidai 天刑星行法次第), and Tenkeisei Rituals (Tenkeisei-hō 天刑星法). The content of these manuals demonstrates that by the Kamakura period, the protective star deity Tenkeisei had been firmly integrated into the esoteric Buddhist pantheon: He is conflated with the Terminator of Death, Yamāntaka (Jpn. Daiitoku myōō 大威徳明王), and both are considered manifestations of the bodhisattva Mañjuśrī (Jpn. Monju bosatsu 文殊菩薩). ${ }^{43}$ Other deities mentioned that are emanations of Mañjuśrī include Gozutennō, Mutōtennō 武答天王, ${ }^{44}$ a Korean deity, and the Eight Princelings. The Tenkeisei Rituals outline the secret method for conducting a possession ritual (Jpn. abisha, transcribed e.g. 阿尾捨, Skt. āveśa) and claims that Kamo no Yasunori brought back the knowledge about the ritual from his travels to China. Yasunori was never in China but must have had access to imported books, so the claim that Yasunori used Chinese books is not entirely unfounded. In my view, mentioning the name of the illustrious yin-yang master serves to indicate that the ritual is linked to that tradition and thereby enhance its value. The manual instructs the ritual expert to make Tenkeisei seals for healing and to introduce various kinds of exorcistic spells and talismans. While all three manuals repeatedly emphasize the strict secrecy of the methods to make sure that Tenkeisei will not mete out heavenly punishments, the large number of wooden talismans (majinai fuda まじない札) dedicated to Tenkeisei dating from the late twelfth to the fifteenth century 45 unambiguously attest to the wide popularization of this deity by that time. ${ }^{46}$ Miyajima also sees a connection to a star called Tenkōsei 天罡星 which has been referred to as a deity—Tenkō myōjin 天罡明神—in Japan. This deity is linked to the Big Dipper constellation. ${ }^{47}$ The Tenkeisei Rituals outline a medical technique that involves rebuking "Tenkō" 天罡, which was possibly used in Japan as another

42 One was copied in the first half of the thirteenth century, the others are from the second half of the Kamakura period (1185-1333). Miyajima 1985, 9.

43 See also Faure 2019, 335-36.

44 Alternative names are Mutōjin and Mutō no kami 武答神.

45 That is, from the second half of the Kamakura to the middle of the Muromachi periods (1333-16oo).

46 Miyajima 1985, 11-12.

47 The Big Dipper constellation also played a certain role in the Japanese history of religion; on the worship of stars in Japan, see the volume edited by Lucia Dolce 2006. 
name for the star. ${ }^{48}$ Tenkō means "heavenly guidelines" and refers to ritual pacing or dancing, which follows basic cosmic patterns such as that of the Big Dipper constellation. In the Chinese Daoist tradition, the term appears in the name of an important talisman of the "Rectifying Rites of the Celestial Heart" (Tianxin zhengfa 天心正法) tradition. ${ }^{49}$ The Rectifying Rites tradition is an exorcistic and therapeutic tradition that became important during the Song dynasty (96o-1279) with the first texts compiled at the beginning of the twelfth century. Knowledge about this talisman may have reached Japan and become a popular part of the ritual service offered by Buddhist monastics, as indicated by the manuals kept at Kōzanji, as well as by Kamo no Yasunori, Abe no Seimei, and their descendants.

The group or "network" of deities that connect Gozutennō and his "family" and Tenkeisei as emanations of Mañjuśrī also came to include Susanoo 素戔 鳴, one of the most revered kami. ${ }^{50}$ Susanoo is known for his wild character and his ability to annihilate snake infestations. After Abe no Seimei's death, his family became close to the Gionsha Shrine ${ }^{51}$ in Kyoto whose cult centered on Mutōtennō/Gozutennō and their "network." According to the Inner Tradition of the Square and the Round Offering Vessels (Hoki naiden 籃笽内伝), 52 a secret divination book ascribed to Abe no Seimei but compiled at the end of the Kamakura period (1185-1333) by one of his descendants, ${ }^{53}$ Tenkeisei and Gozutennō are one and the same.

48 Miyajima $1985,13$.

49 For an image of the tiangang fu 天罡符 (Talisman of the Celestial Guideline), see Andersen 2008, 99o, fig. 73c.

50 Another tradition sees the "Medicine Buddha" Yakushi nyorai 薬師如来 as the male principal Buddhist deity (honji 本地) of the Gion divinity, and the Eleven-Faced Avalokiteśvara (Jūichimen Kannon 十一面観音) as its female principal deity (Nishio 2000, 149-50). For a discussion of Yakushi and the star deity Myōken 妙見 in the context of the Gozutennō belief, see Kawamura 2007, 294-303. On associations of Gozutennō, his kami counterpart Susanoo, and other pestilence deities, see Faure 2016b, 326-27. See also Imahori 1993.

$5^{1}$ For the Gion shrine-temple complex in the Heian period, see McMullin 1987.

$5^{2}$ The full title of this work is Sangoku sōden on'yō kankatsu hoki naiden kin'ugyokuto-shū 三国相伝陰陽輨轄䈍篮内伝金烏玉兔集 (The Collection of Three Countries' Transmission of Yin and Yang, Hoops and Wedges, the Inner Tradition of Square and Round Offering Vessels, Gold Crow [= Sun] and Jewel Rabbit [= Moon]), NKGS 2004, 3:100-162.

Miyata 2012, 126-27. 


\section{Depicting the Nemesis of Epidemic Disease: Gozutennō and Susanoo}

Because of the centrality of the worship of Mutōtennō/Gozutennō, the secret cult to a cruel and baleful star that needed to be summoned and coerced into assisting humans slowly became marginalized, and Mutōtennō/Gozutennō, who was also conflated with Susanoo, eventually moved center stage. ${ }^{54}$ The process was helped by a myth centering on the wrathful but protective character of a heavenly deity, Mutōtennō, that allegedly appeared in one of the earliest textual sources in Japan, the Gazetteers of the Land of Bingo (Bingo no kuni fudoki 備後国 風土記), a myth that was retold time and again with slight changes in the course of Japanese history. ${ }^{55}$ In the story, a poor, older brother, Somin Shōrai 蘇民将来, hosts a traveler who is Mutōtennō in human form, while his wealthy younger brother declines to host the divinity. The grateful Mutōtennō bestows a diseaserepelling wreath made from miscanthus reeds on the kind brother's daughter and instructs her to wear it and say that she is a descendant of Somin Shōrai in order to be safe from disease. ${ }^{56}$ Time passes and Somin Shōrai dies. On his return journey many years later, the divinity, along with his wife, eight children, and a retinue consisting of over eighty-four thousand, kill the surviving younger brother and his family with an epidemic disease but spare Somin Shōrai's daughter who is wearing the wreath. In this narrative, a connection is made between morality and disease as a punishment. The older brother's selfless behavior ultimately protects his descendants. ${ }^{57}$ Although the daughter herself only follows the instructions to wear the amulet, she performs the correct ritual and thus survives the epidemic. The story teaches us that selfless acts have an effect on all of human society. However, while selflessness is to be encouraged, only the precise execution of rituals for divine protection will ultimately make a difference when it comes to survival.

The deities and demons related to epidemics were - and possibly still arenot merely thought to be removed otherworldly beings. Indeed, the Pictures

54 Rituals dedicated to Tenkeisei have continued to be celebrated by members of the Izanagi-ryū いざなぎ流 on'yōdo tradition, however. The Izanagi-ryū is an independent local tradition from Monobeson in Tosa (today Kami City, Kōchi Prefecture) on the island of Shikoku.

55 Bingo no kunifudoki 備後国風土記, NKBT 1963, 2:65-67. See Weiß 2016, 218.

56 For a brief history of the tradition of the uniquely shaped Somin Shōrai talismans, see Ueda 2006. The volume presents such talismans from the Shinano kokubunji temple museum collection.

See also McMullin 1985, 286. 


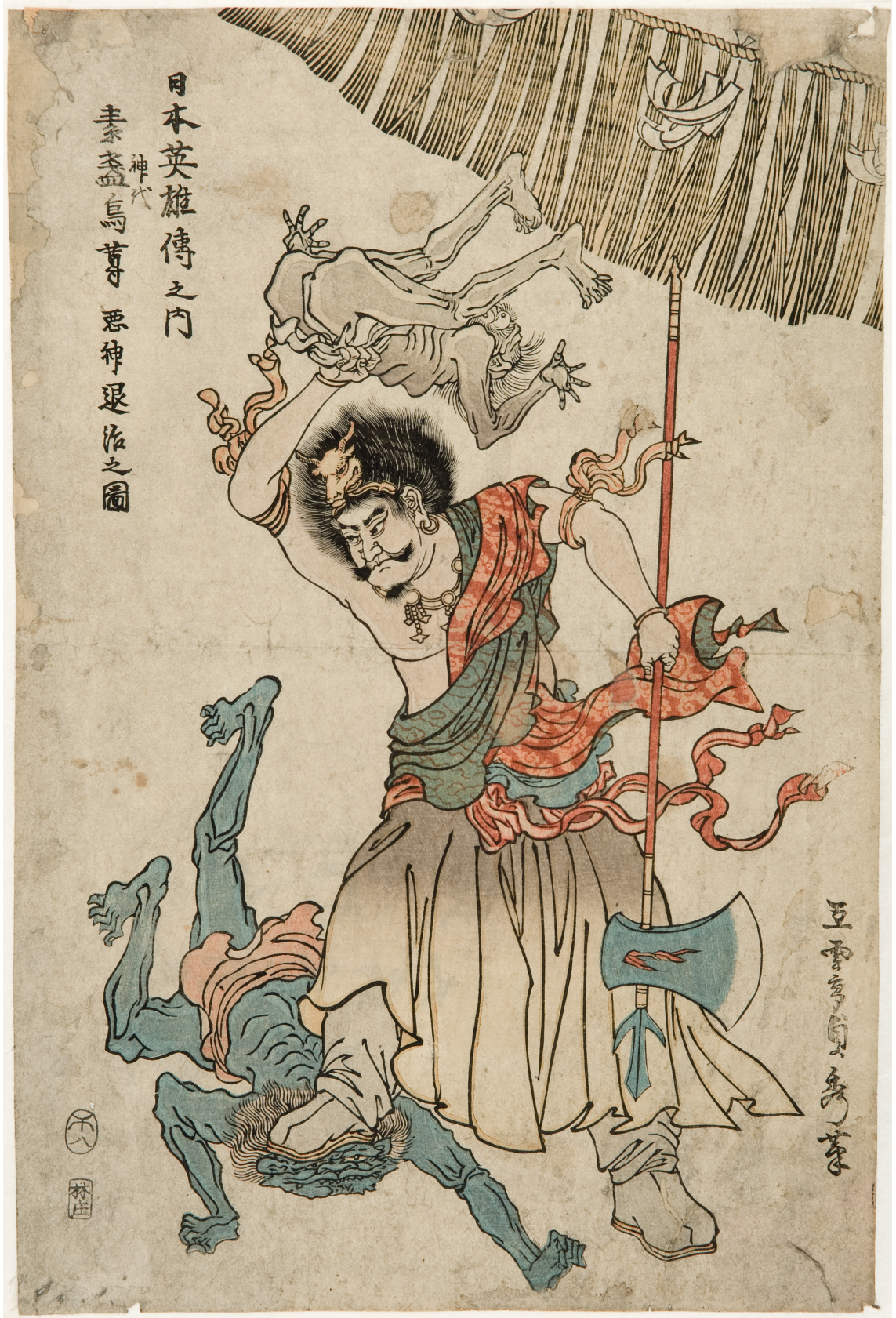

FIGURE 2 Demon-quelling Susanoo/Gozutennō, woodblock print, H. 36 cm, B. 23.5 cm, 1858, Utagawa Sadahide (1807-73), signed: Gountei Sadahide hitsu, Stockholm Museum of Far Eastern Antiquities, Sign. Bekesy-173 
of the Extermination of Evil vividly depict these beings in action. They bring motionless votive images to life and put them in a narrative framework. The twelfth-century picture scroll is unique but later pictorial works of fierce guardian deities prove the richness of this tradition. One popular woodblock print from the nineteenth century depicts, according to the caption, Susanoo as a hero from the ages of gods subjugating evil demons (Figure 2). The picture is part of a series of prints relating Japanese heroic deeds and shows the twoarmed Bull-Headed Divine King, Gozutennō, in the shape of a Wisdom King, armed with a halberd and fighting two demons. The design of the deity faithfully follows medieval Japanese iconography. He crushes one demon with his foot, and lifts the other into the air. The facial expression of the deity is similar to that of Tenkeisei (cf. Figure 1). Gozutennō is busy defending a boundary, as indicated by the straw rope on top of the sheet. The name of the temple-shrine complex has changed from Gionsha in the course of history but the Gion Festival has been celebrated annually nearly without interruption since 970. In 2020 the spectacular procession of floats that is part of the Gion Festival was canceled to prevent the further spread of the coronavirus although the comparatively modest ritual involving Susanoo (Gozutennō), his divine wife, and eight divine children probably did take place. Susanoo is the nemesis of the epidemic agents, his face fierce and stern.

What will the modern biomedical nemesis of the novel coronavirus look like, and how will it be presented? So far, in optimistic reports on the vaccine, stock photos showing a human hand in a surgical glove holding a syringe have replaced the helping hand of the deity combating the disease.

\section{Image Credits}

Figure 1. The photograph by Morimura Kinji 森村欣司 is provided by the Nara National Museum. The hanging scroll belongs to the Nara National Museum Collection.

Figure 2. CC BY, Woodblock print, Inventory No. Bekesy-173. Source: National Museums of World Culture-Museum of Far Eastern Antiquities, Sweden, http://collections.smvk.se/carlotta-om/web/object/113586.

\section{Acknowledgments}

This article results from research conducted at the Centre for Advanced Studies in the Humanities and Social Sciences (CASHss) "Multiple SecularitiesBeyond the West, Beyond Modernities" at Leipzig University. The CASHSs is 
funded by the German Research Foundation. For further information, please consult www.multiple-secularities.de.

\section{About the Author}

Katja Triplett, $\mathrm{PhD}$, was previously a professor of the study of religions at Göttingen University and is currently based at Leipzig University. She is also an affiliate professor at Marburg University. Her main fields of interest are Buddhism; religion and medicine; visual and material culture. Her recent publications include Buddhism and Medicine in Japan (De Gruyter, 2019).

\section{Bibliography}

NKBT: Nihon koten bungaku taikei 日本古典文学大系. Iwanami Shoten, 1958-68.

NKGS:Nihon koten gisho sōkan 日本古典偽書叢刊. Gendai Shichō Shinsha, 2004-2005.

\section{Primary Sources}

Hekija-e 辟邪絵 [Extermination of Evil; five hanging scrolls, twelfth century]. https:// emuseum.nich.go.jp. Accessed July 16, 2021.

Hokinaiden 笽筬内伝 [Inner Tradition of the Square and the Round Offering Vessels]. 2004. In NKGS, edited by Mashimo Miyako and Yamashita Katsuaki, vol. 3, 100-162. Konjaku monogatarish $\bar{u}$ 今昔物語集 [Anthology of Tales from the Past; ca. 1120]. 195963. In Nквт, edited by Yamada Yoshio 山田孝雄 et al., vols. 22-26.

Somin Shōrai 蘇民将来. In Bingo no kuni fudoki 備後国風土記 [Gazetteers of the Land of Bingo]. 1963. In NKBT, vol. 2, 65-67.

Tenkeisei gyōhō 天刑星行法 [Methods of Tenkeisei Practice; thirteenth century]. Kōzanji Temple Archive.

Tenkeisei gyōhō shidai 天刑星行法次第 [Methods of Procedure for the Tenkeisei Practice; fourteenth century]. Kōzanji Temple Archive.

Tenkeisei-hō 天刑星法 [Tenkeisei Rituals; fourteenth century]. Kōzanji Temple Archive.

\section{Secondary Sources and Editions}

Andersen, Poul. 2008. "Tianxian zhengfa." In The Encyclopedia of Taoism, edited by Fabrizio Pregadio, vol. 2, 989-93. London: Routledge.

Baba Akiko 馬場あき子. 2000. “Oni no tanjō”鬼の誕生. In Oni 鬼, edited by Komatsu Kazuhiko 小松和彦, 25-51. Kaii no minzokugaku 怪異の民俗学, vol. 4. Tokyo: Kawade Shobō Shinsha.

Como, Michael. 2007. "Horses, Dragons, and Disease in Nara Japan." Japanese Journal of Religious Studies 34, no. 2: 393-415. 
Dolce, Lucia. 2006, ed. "The Worship of Stars in Japanese Religious Practice." Special issue, Culture and Cosmos 10, no. 1/2: 3-43.

Farris, William Wayne. 1985. Population, Disease, and Land in Early Japan, 645-900. Harvard-Yenching Institute Monograph Series 24. Cambridge, MA: Council on East Asian Studies, Harvard University, and the Harvard-Yenching Institute. Distributed by the Harvard University Press.

Farris, William Wayne. 2009. Daily Life and Demographics in Ancient Japan. Michigan Monograph Series In Japanese Studies 63. Ann Arbor, MI: Center for Japanese Studies, University of Michigan.

Faure, Bernard. 2016a. The Fluid Pantheon. Gods of Medieval Japan, vol. 1. Honolulu: University of Hawai'i Press.

Faure, Bernard. 2016b. Protectors and Predators. Gods of Medieval Japan, vol. 2. Honolulu: University of Hawai'i Press.

Faure, Bernard. 2019. "Decentering Mañjuśrĩ: Some Aspects of Mañjuśrīs Cult in Medieval Japan." In "The International Characteristics of the Wutai Cult," special issue, Studies in Chinese Religions 5, no. 3-4: 330-42.

Fujikawa Yū 富士川游. 1912. Nihon shippei shi 日本疾病史. Tōyō bunko 東洋文庫 133 . Tokyo: Heibonsha.

Guggenmos, Esther-Maria. 2017. "A List of Magic and Mantic Practices in the Buddhist Canon." In Coping With the Future: Theories and Practices of Divination in East Asia, edited by Michael Lackner, 151-95. Sinica Leidensia 138. Leiden: Brill.

Hardacre, Helen. 2016. Shinto: A History. New York: Oxford University Press.

Hayashi, Makoto, and Hayek, Matthias. 2013. "Editors' Introduction: Onmyōdō in Japanese History." In "Onmyōdō in Japanese History," special issue, Japanese Journal of Religious Studies 40, no. 1: 1-18.

Hou, Ching-lang. 1979. "The Chinese Belief in Baleful Stars." In Facets of Taoism: Essays in Chinese Religion, edited by Holmes Welch and Anna K. Seidel, 193-228. New Haven, CT, and London: Yale University Press.

Imahori Taitsu 今堀太逸. 1993. "Ekibyō to jingi shinkō tenkai-Gozutennō to Somin Shōrai no shison” 疫病と神祇信仰の展開-牛頭天王と蘇民将来の子孫. Bukkyōshi-gaku kenkyū 36, no. 2: 1-44.

Itō, Satoshi. 2003. “The Medieval Period: The Kami Merge with Buddhism.” In Shinto: A Short History, edited by Nobutaka Inoue, translated by Mark Teeuwen and John Breen, 63-107. London and New York: RoutledgeCurzon.

Kawamura Minato 川村湊著. 2007. Gozu tennō to Somin Shōrai densetsu: kesareta ishin-tachi 牛頭天王と蘇民将来伝説: 消された異神たち. Tokyo: Sakuhinsha.

Keller Kimbrough, trans. 2018. "The Demon Shuten Dōji (Shuten Dōji)." In Monsters, Animals, and Other Worlds: A Collection of Short Medieval Japanese Tales, edited by Keller Kimbrough and Haruo Shirane, 31-59. New York: Columbia University Press.

Kim, Sujung. 2020. Shinra Myojin and Buddhist Networks of the East Asian "Mediterranean". Honolulu: University of Hawai'i Press. 
Kobayashi Taichirō 小林太市郎. 1974. “Hekija-emaki ni tsuite” 辟邪絵巻に就て. In Yamato-e shiron 大和絵史論, edited by Naya Yoshiharu 納屋嘉治. Kobayashi Taichirō chosaku-shū 小林太市郎著作集 5, Nihon geijutsu-ron hen 日本藝術論篇 1 , 197-274. Tokyo: Tankōsha.

Lin, Irene H. 2002. "The Ideology of Imagination: The Tale of Shuten Dōji as a Kenmon Discourse." Cahiers d'Extrême-Asie 13: 379-410.

Mashimo Miyako 真下美弥子 and Yamashita Katsuaki 山下克明, eds. 2004. "Hoki naiden kin’ugyokuto-shū" 笽笽内伝金烏玉兔集. In Nihon koten gisho sōkan, vol. 3, 100-62. Tokyo: Gendai Shichō Shinsha.

McMullin, Neil. 1987. "The Enryaku-ji and the Gion Shrine-Temple Complex in the Mid-Heian Period." Japanese Journal of Religious Studies 14, no. 2-3: 161-84.

McMullin, Neil. 1988. "On Placating the Gods and Pacifying the Populace: The Case of the Gion 'Goryō' Cult.” History of Religions 27, no. 3: 270-93.

McNeill, William H. (1976) 1998. Plagues and Peoples. New York: Anchor Books.

Miyajima Shin'ichi 宮島新一 1985. “Hekija-e—wagakuni ni okeru juyō” 辟邪絵—わが 国における受容—. Bijutsu kenkyū 33: 177-98.

Miyata, Nana. 2012. "Die Hintergründe der Legendenbildung über Abe no Seimei, dem namhaftesten Divinationsmeister der Heian-Zeit." In Religiöse Tradierung in Japan, edited by Katja Triplett, 119-46. Schriften des Zentrums für Interdisziplinäre Regionalstudien 1. Halle: Universitätsverlag Halle-Wittenberg.

Murayama Shūichi 村山修一. 1981. Nihon Onmyō-dō-shi sōsetsu 日本陰陽道史総説. Tokyo: Hanawa Shobō.

Naumann, Nelly. 2000. “The State Cult of the Nara and Early Heian Periods." In Shintō in History: Ways of the Kami, edited by John Breen and Mark Teeuwen, 47-67. Curzon Studies in Asian Religion. Richmond, Surrey: Curzon Press.

Nishio Masahito 西尾正仁. 200o. Yakushi shinkō: gokoku no hotoke kara onsen no hotoke $e$ 薬師信仰: 護国の仏から温泉の仏へ. Goei shigaku kenkyū-kai, Minzokugaku sōsho 御影史学研究会・民俗学叢書 13. Tokyo: Iwata Shoin.

Phillips, Quitman Eugene. 2019. “Kano Motonobu's Shuten Dōji Emaki and Anti-demon Rituals in Late Medieval Japan." Japan Review 3: 245-68.

Reider, Noriko T. 2010. Japanese Demon Lore: Oni from Ancient Times to the Present. Logan: Utah State University Press.

Reider, Noriko T. 2016. Seven Demon Stories from Medieval Japan. Logan: Utah State University Press.

Shively, Donald H., and William H. McCullough, eds. 1999. Heian Japan. The Cambridge History of Japan, vol. 2, edited by John Whitney Hall, Marius B. Jansen, Madoka Kanai, and Denis Twitchett. New York: Cambridge University Press.

Strickmann, Michel. 2002. Chinese Magical Medicine. Edited by Bernard Faure. Stanford, CA: Stanford University Press. 
Suzuki Kōtarō 鈴木耕太郎. 2019. Gozu tennō shinkō no chūsei 牛頭天王信仰の中世. Kyoto: Hōzōkan.

Takahashi Masaaki 高橋昌明. (1992) 2005. Shuten Dōji no tanjō: mo hitotsu no nihon bunka 酒吞童子の誕生: もうひとつの日本文化. 中公文庫. Tokyo: Chūō Kōronsha.

Triplett, Katja. 2019. "Pediatric Care and Buddhism in Premodern Japan: A Case of Applied 'Demonology'?" In "Religion and Medicine," edited by Katrin Killinger, Christoph Kleine, and Katja Triplett, special issue, Asian Medicine 14, no. 2: 355-82.

Tyler, Royall. 1987. Japanese Tales. Selected, edited, and translated by Royall Tyler. New York: Pantheon Books.

Ueda shiritsu Shinano kokubunji shiryō-kan 上田市立信濃国分寺資料館, ed. 2006. Somin Shōrai fu: sono shinkō to denshō 蘇民将来符: その信仰と伝承. 3rd ed. Ueda: Ueda shiritsu Shinano kokubunji shiryō-kan.

Uzumaki Megumi 渦巻恵. 2017. “'Kamo no Yasunori no musume no shū' no nagauta no tokushitsu: josei ga nagauta wo yomu toki”『賀茂保憲女集』の長歌の特質: 女性が 長歌を詠屯時. Nihongo to Nihon bungaku 61/62: 29-39.

Weiß, David. 2016. "Constructing Identity through Myth: Susanowo as a Liminal Figure in Discourses on Japanese and Korean Identity." PhD dissertation. University of Tübingen. 